\title{
The Governance Of Border Areas' Determination In Riau Province
}

\author{
Ahmad Fitra Yuza \\ Universitas Islam Riau \\ Pekanbaru, Indonesia \\ Email: Ahmad_ahfy@yahoo.com
}

\author{
Nandang Alamsah Deliarnoor \\ Universitas Padjadjaran \\ Bandung, Indonesia \\ Email : nandangalamsah@gmail.com
}

\begin{abstract}
This paper discusses governance in managing border areas. This is related to the establishment of five villages located between Kampar and Rokan Hulu regency of Riau Province. this issue raises many issues so it is very interesting to discuss both on the theoretical and practical level. Various rare phenomena arose on the question of determining the five villages, including the emergence of a dual government that equally received legitimacy from the local community.This discussion tries to focus on how the implementation of the principles of good governance on the governance, both on the policy scope and at the level of implementation. It aims to understand the question of government accountability in realizing good governance. This paper explores thoroughly the various constraints so that the principles of accountability do not materialize as the democratic state seeks to achieve. The results of this discussion found that governance can not be realized properly. this is seen from several principles such as accountability, transparency, participation and law enforcement in the determination of the five village areas can not be realized. The logical consequence of this led to a government decision stating that five villages belonging to Kampar regency government received rejection from the majority of the five villages and by the government of Rokan Hulu Regency. in the end still the dualism of village administration in the same region.
\end{abstract}

Keywords: Accountability, Governance

\section{INTRODUCTION}

This study would like to explore various issues related to the determination of five villages located in the border region between Kampar district and Rokan Hulu regency in Riau Province. As it is understood that the village is a foundation in the development and service the interests of local communities. It seems that Labolo stated that the arrangement of village existence through Law No. 6 of 2014 should be recognized as providing opportunities for the growth of village autonomy. A number of pressures in some chapters provide a discourse that allows the autonomy of the village to grow along with several conditions that must be considered by village government, village communities, local government and central government. Terms are important to be a major concern if you do not want to see the condition of the village increasingly unfortunate fate. From the aspect of authority based on the right of origin as recognized and respected by the state. It appears that the subsidiarity principle underlying the village law provides discretion in determining local authority and decision-making locally for the benefit of local communities (Labolo 2015) [1]. Of course this would be a dilemma if the boundary issue becomes an obstacle in the administration of the village administration.

Regarding the border issues affecting the administration of the village government, the researcher tries to discuss a case related to the boundary issue. Firstly researchers tried to describe the description of the chronology of border phenomena that occurred in Riau Province. The boundary issue between Kampar District and Rokan regency is related to five villages. It started from 1999 until now, the division is based on Law No. 53 of 1999 on the establishment of Rokan Hulu and Pelalawan districts. Kampar regency is a mothership district that directly borders with Rokan Hulu District. The conflict occurred in the border areas of five villages, each district claiming that five villages were included in the expansion area.

The boundary is a problem that is widely updated by various areas in the air soil, of course this will have an impact on the implementation of the appropriate local government such as village administration. Must be understood as a village is an important thing in development today, in addition as a development program. Not surprisingly, various pro- plampun are designed to support the implementation of village government. In accordance with the mandate of Law no. 6 year 2014 on the Village, the purpose of village development is to improve the welfare of rural communities and the quality of human life and poverty alleviation through the fulfillment of basic needs, development of facilities and 
infrastructure, building local economic potentials, and direct utilization of natural resources. sustainable.

The dispute over these five villages continues to roll until this border issue enters the jurisdiction of the Supreme Court of Justice No. 39 K / TUN / 2011 in which five villages are contested in the parent district region of Kampar regency. This decision was confirmed by the Minister of Home Affairs Regulation No. 39 of 2015 on codes and data on administrative regions of government, which included all five villages in Kampar District. However, post-establishment of this boundary does not make all parties satisfied. This is marked by the conflict between the government which leads to the existence of double village government that is five village version of Rokan Hulu Regency and five village version of Kampar regency.

Discussion on this paper is the development of research results that aims to find answers on how the implementation of good governance principles related to the establishment of the boundaries of five villages located between Kampar and Rokan Hulu. Boundary is a problem that many faced by various regions across the country, this issue will certainly have an impact on the implementation of local government, especially border areas such as village government. In this case the researchers will see how the process of implementing the principles of good governance in the determination of five villages.

\section{SCOPE OF QUESTION}

This study uses a qualitative approach to describe the various phenomena that occur, as stated by Creswell explains that qualitative research is as a process of investigation to understand social problems or human problems, based on the creation of a complete holistic picture formed in words, reporting the views of informants in detail, and arranged in a natural setting Creswell (1994: $1)$.

As for the research questions to be answered are:

How is the Governance of Border Area Determination of Five Villages in Kampar District?

\section{DISCUSSION}

This discussion uses several concepts that have been expressed by several experts who share the same view of the use of good governance, Bhatta (1996), Tjokroamodjojo (2000) and Smit (2007). According to Bhatta stated that good governance contains the main elements consisting of: accountability, transparency, openness, and rule of law (Bhatta, 1996) [3].

Similarly, Smit also pointed out that governance contains principles consisting of: accountability, transparency, participation, law enforcement, corruption prevention, poverty alleviation, deal orientation, future insight and decentralization (Brian C.Smit 2007) [4]. In this discussion the author uses only four indicators used as a knife analysis is as follows:

\section{A. Accountability}

The accountability process is the most important thing the government should do, as what Moncrieffe says explains that accountability has two dimensions: (1) ex post facto (principle of normative accountability) in principle requires officials and public institutions to be responsible for the available authority they go through. (2) ex-ante (positive accountability) essentially requires public officials to always represent the wishes of the people in every policy implementation they take. They should constantly consult every action on the public, provide alternative solutions and check the quality of policy officials and revise it if it is deemed necessary Moncrieffe (in Setiyono; 2014; 184-185) [5]. It can be concluded that conceptually accountability gets the most important role to improve a system as a process in a government activity.

Based on the facts in the field shows that neither the normative accountability nor the positive accountability dimension can be realized properly, because the government of Rokan Hulu Regency still does not accept the Regulation of the Minister of Home Affairs No. 39 of 2015 on the code and data of the administrative area of government, which lists all five villages into the government territory Kampar District. This rejection occurred because of various causes such as in 2010 there has been a decision that five villages into Rokan Hulu District region and not accommodated the wishes of most of the five villagers who stated that they still want to join the government of Rokan regency.

As a result of the rejection of the determination of this region makes the dualism of village governance still occur. This led to various dilemmas in the community because they were administratively provided services from the village version of Kampar Regency and the village of Rokan Hulu Regency. Accountability of the government becomes very complicated on the other hand there has been provision that the five village versions of Kampar regency get authority in the implementation of its function, but received rejection from the majority of society in the five villages.

\section{B. Transparency}

Transparency is the government's openness to the community regarding its tasks and functions. According to Bhatta a good government will be transparent to its people, both at the central and regional levels. The people know clearly and without any cover-up about the process of public policy formulation and its implementation actions Bhatta (1996). In view of the transparency of the government in determining the area of five villages in Kampar regency can be seen from several things namely the stages in the determination as a manifestation of the will of the community and the openness of government in realizing the policy in favor of the community.

The stages in the establishment of five villages within Kampar regency government area through various long process that is from 1999 until until 2015. In the process of determination there is a struggle of interests 
between districts adjoining government. In fact, up to now, many of the five villages that have identities from five villages in Rokan Hulu District indicate that the decision given by the central government is not based on the aspirations of the people residing in the five villages.

The government's openness in adopting a policy must be demonstrated by both the central government and the local government. Although there have been various mediations between the border district governments but still bring up various problems. Many people think that after the determination of five villages into Kampar district area in 2015 did not solve the problem. This is evidenced by the existence of dualism of government. The facts in various functions of the village government can not work properly. Each of the villages continues to carry out various activities of service, this makes the community divided into two groups namely the first group of pro against the government of Kampar regency and the second group counter against it so choose to side with the village version of Rokan Hulu District.

\section{Partisipation}

Participation is the involvement of the community both in the formulation and implementation of the policy. There are several findings in the field that indicate that the parcipaon of villagers in the five villages is very low against the determination made by the government related to the five villages. This can be seen from the condition of the five villages, namely Intan Jaya Village, Tanah Datar Village, Muara Intan Village, Rimba Jaya Village, and Rimba Makmur Village are transmigration settlements that are part of the village of senamanenek of Siak Hulu subdistrict of Kampar regency. On October 4, 1999, Law No.53 / 1999 on the formation of Pelalawan Regency, Rokan Hulu Regency, Rokan Hilir Regency, Siak Regency, Karimun Regency, Natuna Regency, Kuansing Regency and Batam City was established. Article (4) mentions that Kunto darus subdistrict is included in Rokan Hulu Regency, but does not mention which villages belong to Kunto darusalam sub-district.

It is also based on the field indicating that most of the five villages have the assumption that with the spreading of Rokan Hulu regency, the sub-districts and villages that enter into the area will be under the auspices of the expanded government. These conditions make the community of five villages believe that the status of the village is under the auspices of the government of Rokan Hulu Regency. this is also supported by the development undertaken by the district government after the expansion of the new district.

This fact is also supported by the issuance of the letter of the Minister of Home Affairs number: 135.6 / 824 / SJ dated March 2, 2010 regarding the affirmation of the position of the five villages mentioned that the five villages are in Rokan Hulu District. this policy is a foundation for the government of the five villages to keep doing the services properly, so that most of the assets are managed by five villages under the aegis of Rokan Hulu Regency. at the same time five Kampar regency village villages also continued to provide services to the five villages. This was marked by a lawsuit by a five-village BPD with lawsuit No. 17 / B / 2011 / PT.TUN.JKT with the decision to grant the plaintiff's claim and cancel the letter of the interior minister on the position of five villages. Various processes traversed finally five villages entered in Kampar regency.

Through a variety of processes that long enough to bring a variety of policy changes and create a group of pros and cons in the community. This study found that although the conflict between the government on the status of the five villages did not make the inter-community relations in the five villages to be bad. The daily relations between the people of both pro and contra are going accordingly, the policy changes do not affect the good relations that have occurred between communities so far.

The results of this discussion concluded that there are some things that affect the condition of society related to the demographic services carried out by the five villages namely; Firstly, there is a pattern of changes such as the division of legislation and the decision of the minister of interior which initially determined the five villages to enter the Rokan Hulu regency, so that when there is a final verdict that sets five villages into Kampar regency does not affect the perception of the community. Secondly, any change of policy or administrative matters can disrupt the social fabric of society.

\section{Law enforcement}

Law enforcement can be understood as an attempt to curb, social engineering or speak of a legal certainty. According to Roscue emphasized the importance of law as a means of social engineering, especially through a case resolution mechanism by the judiciary that would result in the Roscue Pound jurisprudence in Hadjon (2010) [6]. Related to the determination of five villages included in the Kampar District experienced various stages of the settlement through legal channels, but this still raises various problems in implementing legal certainty that get rejection from majority of society in five border villages.

The opposition went through various stages: the Minister of Home Affairs issued a letter No. 126/2505 / SJ dated August 19, 2008, which was given to the Governors, Regents and Mayors throughout Indonesia, related to the affirmation of regional boundaries between provinces, districts and cities. In the letter was affirmed on the Regulation of the Minister of Home Affairs No. 1 of 2006 on Guidelines for Affirmation of Regional Boundaries. As a follow up of the Minister of Home Affairs letter No.126 / 2505 / SJ, on 17 September 2009, the Ministry of Home Affairs of the Republic of Indonesia issued a letter number $136 / 1431 . P U M$ on the settlement of five villages between Rokan Hulu and Kampar districts. The letter of the Ministry of Home Affairs contains the affirmation of the status of five villages included in the administrative area of Rokan Hulu Regency. The letter of the Ministry of Home Affairs was reaffirmed by a letter of the Minister of Home Affairs Number 135.6 / 824 / SJ dated March 2, 2010 stating that the status of five villages was decided to be 
included in Rokan Hulu Regency. And for the assurance of confirmation of Kampar Regency boundary with Rokan Hulu regency, it will be facilitated by the government of Riau Province based on the Minister of Home Affairs Regulation No. 1 of 2006.

Responding to the decision of the Minister of Home Affairs, the village representative agency (BPD) of five villages from the district government of Kampar appealed to the Jakarta State Administrative High Court but was rejected by the decision of the State Administrative High Court Number 17 / B / 2011 / PT.TUN.JKT dated 02 August 2011. So that the five villages BPD stated cassation to the Supreme Court of the Republic of Indonesia.

From the case of the cassation, the Supreme Court of the Republic of Indonesia issued the Supreme Court decision Number 395 K / TUN / 2011 dated September 10, 2011 which essentially contains the annulment of the Jakarta High Administrative Court Decision Number 17 / B / 2011 / PT.TUN.JKT, and upheld the ruling of PTUN Jakarta Number 65 / G / 2010 / PTUN-JKT which annulled the Decree of the Minister of Home Affairs Number 135.6 / 824 / SJ dated March 2, 2010 regarding the affirmation of the status of the five villages

Based on the Decree of the Minister of Home Affairs, the Minister of Home Affairs issued Regulation No. 39 of 2011 on the Code and Data of Administration Administration Area which stated that five villages belong to Kampar Regency and revised by Permendagri no 56 2015 and then reaffirmed by the governor of Riau with no letter: 136 ADM-XI- 2016-674 for the implementation of five villages (Muara Intan Village, Tanah Datar Village, Rimbo Jaya Village, and Desa Rimba Makmur implemented by Kampar regency government.

The existence of legal certainty about the status of the five villages should eliminate various doubts to the community, but this still raises many problems in the community, because based on the data field shows that the majority of the five villagers still choose the services organized by the Rokan Hulu government, because from the beginning of the fifth expansion the village of Suda serves the community. In relation to the decision of the Supreme Court, the people do not believe it because from the beginning of the division of the five villages there has been a tug on the status of the territory. This is also reinforced by information from various parties that explain about the rejection both from the government of Rokan Hulu District and some of the five villages on the decision or policy that has been determined.

The result of this study concludes that there are two issues that make law enforcement unreal in its application in the community: First, there is no administrative sanction to the Rokan Hulu regency government towards the implementation of the five postdetermining village services which clearly states the five villages are included in Kampar District. Secondly, the disobedience of some of the five villages based on various phenomena that have occurred both pre and post the establishment of the five villages. Both of these make the administrative services of the five villages to be unadjusted as appropriate and existing legal or policy decisions seem to be something that has not been finalized.

\section{CONCLUSION}

Based on the results of discussion, it can be concluded both theoretically and paraktically that the governance in the determination of the border areas of five villages can not be realized because of the implementation of principles of accountability, transparency, participation and law enforcement. The government policy based on the Supreme Court decision. 39 K / TUN / 2011 The Minister of Home Affairs issued Regulation of the Minister of Home Affairs No. 39 of 2011 on Code and Data of Government Administration Area and revised by Permendagri no 562015 which states five villages entered in Kampar regency. This was rejected by the majority of the five villages and the district government of Rokan Hulu, so that there was still the dualism of the village administration.

\section{REFERENCES}

[1] Labolo, Muhaddam. Dinamika Politik \& Pemerintahan lokal.Bogor. Ghalia Indonesia, 2015,pp 174

[2] Cresswell, John W.Research Design Qualitative \& Quantitative Approaches. Thousand Oaks: Sage Publication,1994. pp 1

[3] Bhatta,Gambhir."Capacity Building at the lokal Level for Effective Governance; Empowerment Without Capacity is Meaningless"; Paper presented in the international Comference on governance Innovation: Building the Government-Citizen Business Partnership, Oktober 20-23 Manila. Philippines.1996.pp 7.

[4] Smit, Brian C. Good Governance and Depelopment.New York : Palgrape Macmillan.2007.

[5] Setiyono, Budi. Pemerintahan dan Manajemen Sektor Publik, PrinsipPrinsip Manajemen Pengelolaan Negara Terkini. Yogyakarta, Center of Academic Publishing Service (CAPS), 2014,pp 184-185.

[6] Hadjon, Philipus M. Dkk. Hukum Administrasi dan Good Governance. Jakarta: Universitas Trisakti,2010. 